\title{
An Investigation on Anxiety States of Students in Faculty of Sport Sciences During COVID-19
}

\author{
Kürşat $\mathrm{ACAR}^{1}{ }^{(\mathrm{D})}$, Ahmet $\mathrm{MOR}^{2}$, Kadir BAYNAZ ${ }^{3}$ and Erkal ARSLANOGLU ${ }^{4}$ (D)
}

${ }^{1}$ Sinop University, Faculty of Sport Science

*Corresponding author: kursatacar@ sinop.edu.tr

\begin{abstract}
This study aims to investigate anxiety states of students in Faculty of Sport Sciences during coronavirus (Covid19) in terms of some variables. Total number of 166 students as 67 female and 99 male chosen by simple random sampling from Sinop University Faculty of Sport Sciences participated in this study. Informed consent form and Beck Anxiety Inventory were used as data collection tool. To disclose differences in statistical evaluation of the data Mann-Whitney U Test and for multiple comparisons Kruskal-Wallis Test were used. In paired comparison of the total scores in anxiety inventory, it was detected statistically difference with regards to gender variable in favor of males $(\mathrm{p}<0,05)$. On the other hand, there were not found any statistically significant difference in age, monthly personal income, home exercise status, exercise frequency, exercise duration, habit of cigarette smoking and following virus news at daily basis during coronavirus threat $(p>0,05)$. Anxiety levels of females participated in this study were found higher than males. No statistically significant difference was found in home exercise. But, anxiety levels of the participants exercised at home were observed lower compared to the others who did not.
\end{abstract}

Keywords

Exercise, anxiety, covid-19, coronavirus.

\section{INTRODUCTION}

Having been detected with the clusters of pneumonia in China at December 19, the pandemic started to be seen in our country in March 2020 (He et al., 2020). This pandemic was called as 'Severe Acute Respiratory SyndromeCoronavirus-2' (SARS-CoV-2) and the disease that it causes was named as Covid-19 (Corona Virus Disease 2019), by World Health Organization (Ignatowicz et al., 2019; Priya, 2020). Number of cases increased rapidly after officially announced to be seen in our country March 11, 2020. Rapid increase in numbers of the infected people was accompanied with some serious measures consecutively. The measures taken in our country were determined as prohibitions and guidelines. In this context, in our country as gradually; education (in-person class) was suspended, implementation of distance learning began, and people over the age of 65 and under the age of 20 were imposed a curfew. Besides, government agencies and experts called for 'staying at home' so as to keep people in selfisolation, by using mass communication. In this way, social interaction and contact of the people were reduced to minimum levels. People strived to stay at home in this isolation period, and this new routine and uncertainty led to anxiety. So, the concept of 'anxiety' became an important topic needs to be focused in this period.

Colloquial speech usage of this concept via translation was added to our language as 'concern/apprehension/worry' that could not meet the same meaning as in English. So, psychiatry experts who thought this usage causes loss of 
meaning, managed to replace it with 'anxiety' in scientific language and started to use it (Öztürk, 2004). The concept of anxiety, on the other hand, is considered as both symptom and also the reason of mental disorders by the experts. According to the researchers, anxiety is the expression of the fight-or-flight reaction which prepares human organism to physically move in case of danger (Beck, 2008).

Anxiety is an important health problem affects both individual and society. In treatment of the anxiety, medication is also given together with several methods. In addition, the effects of sport and exercise on mental health have been examined by many researchers (Byrne and Byrne, 1993; Salmon, 2000). These researchers have suggested that sport provides improvement on mood thanks to its physiological and biological characteristics (Dishman et al., 1997). Lawlor and Hopker (2001), Mead et al. (2009), on the other hand, have pointed out that there is a relationship between exercise and reducing of the depression symptoms. Sport, therefore, has been thought to be an implement producing positive effects on mental health. In this context, purpose of our study is to investigate the anxiety levels of the students, from Sinop University Faculty of Sport Sciences, in terms of some variables.

\section{MATERIALS AND METHODS}

\section{Research design}

This research was correlational survey model with cross-sectional and descriptive characteristics. Prior to this study, the application was made to Sinop University Human Research Ethics Board. In accordance with the Human Research Ethics Board decision dated 20/05/2020 and numbered $2020 / 51$, it was pronounced that this research is compliance with the Human Research Ethics Board Guideline and there is no inconvenience ethically.

\section{Participants}

Sinop University Faculty of Sport Sciences (2019-2020 Academic Year, 263 students) comprised the population, whereas total number of 166 students as 67 female and 99 male selected randomly constituted the sample of the research.

\section{Data Collection}

Survey method was used as data collection tool in the study. Questionnaire prepared by the researcher consisted of two sections. 'Personal
Information Form' in the first part and 'Beck Anxiety Inventory' in the second part were located. Questions were prepared by using 'Google Forms' so that it helps the students reach to the questionnaires easier. Introductory text of the questionnaire and online form link were sent to the students through e-mail and text message. Questionnaire remained as open access for three weeks, the questionnaire then was stopped when data entry was over and data set was made ready for the statistical analysis.

\section{Personal Information Form}

Participants were asked to respond the questions such as gender, age, home exercise status, exercise frequency, exercise duration, habit of cigarette smoking and the status of following virus news at daily basis during coronavirus.

\section{Beck Anxiety Inventory}

It is a Likert type self-assessment inventory created by Beck et al. (1961) consisted of 21 questions and scored between 0-3. Higher score demonstrates higher anxiety level in an individual. Validity and reliability study was performed by Ulusoy et al. (1998), and they found Cronbach's Alpha reliability (internal consistency) score as 0,93 . Cronbach's Alpha reliability score for this study was determined as 0,89 .

\section{Statistical analyses}

To control if the error terms show normal distribution, Shapiro-Wilk Normality test was used prior to the test selection which would be then applied to the obtained data of the study $(\mathrm{p}<0,05)$. Mann Whitney U test for paired comparisons and Kruskal Wallis test for multiple comparisons were utilized in total scores obtained from inventory. Research findings were expressed as n, (\%), mean and standard deviation, and accepted as $\mathrm{p}<0,05$ level of significance. All statistical calculations were made by using SPSS $22.0 \mathrm{~V}$. statistical package.

\section{RESULTS}

In paired comparison of the total scores in anxiety inventory, it was detected statistically difference with regards to gender variable in favor of males $(p<0,05)$. On the other hand, there were not found any statistically significant difference in age, monthly personal income, home exercise status, exercise frequency, exercise duration, habit of cigarette smoking and following virus news at Daily basis during coronavirus threat $(\mathrm{p}>0,05)$. 
Table 1. Frequency and Percentage Distribution of The Participants in Terms of Their Demographic Information

\begin{tabular}{|c|c|c|}
\hline Gender & $\mathbf{n}$ & $\%$ \\
\hline Female & 67 & 40,6 \\
\hline Male & 99 & 59,4 \\
\hline Total & 166 & 100,0 \\
\hline \multicolumn{3}{|l|}{ Age } \\
\hline $17-19$ & 38 & 22,9 \\
\hline $20-22$ & 94 & 56,6 \\
\hline $23-25$ & 34 & 20,5 \\
\hline Total & 166 & 100,0 \\
\hline \multicolumn{3}{|l|}{ Monthly Personal Income } \\
\hline $500 \mathrm{tl}$ and under & 39 & 23,5 \\
\hline $501 \mathrm{tl}$ and $1000 \mathrm{tl}$ & 51 & 30,7 \\
\hline $1001 \mathrm{tl}$ and $1500 \mathrm{tl}$ & 22 & 13,3 \\
\hline $1501 \mathrm{tl}$ and $2000 \mathrm{tl}$ & 18 & 10,8 \\
\hline $2000 \mathrm{tl}$ and over & 36 & 21,7 \\
\hline Total & 166 & 100,0 \\
\hline \multicolumn{3}{|l|}{ Home Exercise Status } \\
\hline Regularly & 80 & 48,2 \\
\hline Never & 35 & 21,1 \\
\hline Sometimes & 51 & 30,7 \\
\hline Total & 166 & 100,0 \\
\hline \multicolumn{3}{|l|}{ Exercise Frequency } \\
\hline $1-2$ times in a week & 47 & 28,3 \\
\hline 3-4 times in a week & 58 & 34,9 \\
\hline 5 times and more in a week & 26 & 15,7 \\
\hline Total & 131 & 78,9 \\
\hline \multicolumn{3}{|l|}{ Exercise Duration } \\
\hline 15 minutes & 17 & 10,2 \\
\hline $16-30$ minutes & 37 & 22,3 \\
\hline $31-45$ minutes & 39 & 23,5 \\
\hline 1 hour and over & 38 & 22,9 \\
\hline Total & 131 & 78,9 \\
\hline \multicolumn{3}{|l|}{ Smoking Status } \\
\hline Yes & 51 & 30,7 \\
\hline No & 98 & 59,0 \\
\hline Sometimes & 17 & 10,2 \\
\hline Total & 166 & 100,0 \\
\hline \multicolumn{3}{|c|}{ Status of Following COVID-19 News } \\
\hline Yes & 136 & 81,9 \\
\hline No & 30 & 18,1 \\
\hline Total & 166 & 100,0 \\
\hline
\end{tabular}

When Table 1 is examined, the ratio of the participants seems to be as $46.6 \%$ female and $59.4 \%$ male. The responses of the students with regard to the variable of home exercise were determined as $48.2 \%$ regular, $21.1 \%$ never and
$30.7 \%$ sometimes. Besides, smoking status of the participants, that considered as risk group vulnerable to coronavirus by experts, were found as $30.7 \%$ yes, $59.0 \%$ no and $10.2 \%$ sometimes. 
Table 2. Anxiety Levels of The Participants in Terms of Gender Variable

\begin{tabular}{lcccccc}
\hline Gender & n & Mean & Std. Dev. & Median & IQR & p \\
\hline Female & 67 & 32,83 & 7,92 & 31,00 & 14,00 & \multirow{0}{*}{, 001} \\
Male & 99 & 26,14 & 5,64 & 24,00 & 6,00 & \\
\hline
\end{tabular}

When Table 2 is considered, participants' favour of the males $(p<0,05)$. So, anxiety levels of scores obtained from the anxiety inventory in the female participants were found higher. terms of gender variable show significance in

Table 3. Anxiety Levels of The Participants in Terms of Their Age

\begin{tabular}{lcccccc}
\hline Age & n & Mean & Std. Dev. & Median & IQR & p \\
\hline 17-19 years & 38 & 26,84 & 5,31 & 26,00 & 8,25 & \\
22-20 years & 94 & 30,12 & 8,01 & 28,00 & 13,00 & 0,100 \\
23-25 years & 34 & 27,76 & 7,15 & 25,50 & 7,75 & \\
\hline
\end{tabular}

As it is seen in Table 3, any statistical difference was not found in anxiety levels of the students in terms of age variable $(\mathrm{p}>0,05)$.

Table 4. Anxiety Levels of The Participants in Terms of Their Monthly Personal Income

\begin{tabular}{lcccccc}
\hline Personal Income & n & Mean & Std. Dev. & Median & IQR & p \\
\hline 500 tl and under & 39 & 29,64 & 8,27 & 25,00 & 12,00 & \\
$501 \mathrm{tl}$ and $1000 \mathrm{tl}$ & 51 & 29,24 & 7,84 & 27,00 & 12,00 & \\
$1001 \mathrm{tl}$ and $1500 \mathrm{tl}$ & 22 & 26,95 & 4,67 & 26,50 & 6,25 & 0,958 \\
$1501 \mathrm{tl}$ and $2000 \mathrm{tl}$ & 18 & 28,94 & 8,56 & 26,00 & 8,50 & \\
$2000 \mathrm{tl}$ and over & 36 & 28,72 & 6,65 & 28,00 & 9,25 & \\
\hline
\end{tabular}

When Table 4 is considered, monthly personal incomes of the participants demonstrate no statistical significance $(\mathrm{p}>0,05)$.

Table 5. Anxiety Levels of The Participants in Terms of Home Exercise Status

\begin{tabular}{lcccccc}
\hline Exercise & n & Mean & Std. Dev. & Median & IQR & p \\
\hline Regularly & 80 & 28,78 & 8,22 & 26,00 & 9,75 & \\
Never & 35 & 29,80 & 6,72 & 29,00 & 11,00 & 0,332 \\
Sometimes & 51 & 28,43 & 6,52 & 27,00 & 10,00 & \\
\hline
\end{tabular}

When table 5 is examined, variable of home exercise status of the participants display no statistical significance $(\mathrm{p}>0,05)$. But, according to the obtained data; anxiety levels of the people who do not exercise at home were found higher.

Table 6. Anxiety Levels of The Participants In Terms of Home Exercise Frequency

\begin{tabular}{lclcccc}
\hline Exercise Frequency & n & Mean & Std. Dev. & Median & IQR & p \\
\hline 1-2 times in a week & 47 & 28,82 & 6,39 & 27,00 & 12,00 & \\
3-4 times in a week & 58 & 29,43 & 8,68 & 27,00 & 9,50 & 0,056 \\
5 times/more in a week & 26 & 25,46 & 4,81 & 25,00 & 7,00 & \\
\hline
\end{tabular}



$(\mathrm{p}>0,05)$.

Exercise frequencies of the students show no statistical difference according to the table 6

Table 7. Anxiety Levels of The Participants in Terms of Exercise Duration

\begin{tabular}{lcccccc}
\hline Exercise Duration & n & Mean & Std. Dev. & Median & IQR & p \\
\hline 15 minutes & 17 & 25,00 & 4,31 & 25,00 & 5,00 & \\
16-30 minutes & 37 & 29,70 & 7,62 & 28,00 & 11,00 & 0,069 \\
31-45 minutes & 39 & 28,24 & 7,96 & 26,00 & 10,00 & \\
1 hour and over & 38 & 29,51 & 7,73 & 28,00 & 11,00 & \\
\hline
\end{tabular}

When table 7 is examined, no statistical difference was detected in students' exercise durations $(\mathrm{p}>0,05)$.

Table 8. Anxiety Levels of The Participants in Terms of Their Smoking Status

\begin{tabular}{lcccccc}
\hline Smoking & n & Mean & Std. Dev. & Median & IQR & p \\
\hline Yes & 51 & 28,90 & 7,31 & 27,00 & 9,00 & \\
No & 98 & 28,76 & 7,60 & 26,00 & 11,00 & 0,605 \\
Sometimes & 17 & 29,58 & 6,85 & 28,00 & 8,00 & \\
\hline
\end{tabular}

Smoking habits of the participants indicate no significance according to table 8 ( $p>0,05)$.
However, non-smokers' anxiety scores were identified lower than smokers.

Table 9. Anxiety Levels of The Participants in Terms of Following COVID-19 News

\begin{tabular}{lcccccc}
\hline Following COVID-19 news & n & Mean & Std. Dev. & Median & IQR & p \\
\hline Yes & 136 & 28,75 & 7,43 & 27,00 & 9,00 & 0,570 \\
No & 30 & 29,53 & 7,34 & 33,00 & 27,00 & \\
\hline
\end{tabular}

When table 9 is regarded, no statistical difference was detected in multiple comparison in

\section{DISCUSSION}

In this study, it was aimed to investigate the anxiety states of the students, who study in Sinop University Faculty of Sport Sciences, during Coronavirus in terms of some variables. Participants seem to be as $46,6 \%$ female and $59,4 \%$ male in this study. The responses of the students with regard to the variable of home exercise were determined as $48.2 \%$ regular, $21.1 \%$ never and $30.7 \%$ sometimes. Moreover, smoking status of the participants, that considered as risk group vulnerable to coronavirus by experts, were found as $30.7 \%$ yes, $59.0 \%$ no and $10.2 \%$ sometimes (Table 1).

When the study is examined in terms of gender variable, the scores obtained from anxiety inventory display statistical significance in favour of males $(\mathrm{p}<0,05$; Table 2$)$. Anxiety levels of the terms of status of following coronavirus news $(\mathrm{p}>0,05)$.

female participants were found higher according to the above mentioned obtained data. Kinrys and Wyngant (2004), pointed out that women have higher risk of developing lifetime anxiety levels, compared to the men. Ateş et al. (2018) in their study with the caregivers of cancer patients; stressed that anxiety and depression states of the women are significantly higher than men. Keskin et al. (2013), reported mental disorders are more prevalent in women depending on reasons such as social, cultural, economic and biologic. Bayraktar et al. (2014), investigated the anxiety levels of the prospective teachers in terms of sport and different variables, they then discovered statistical significance in gender variable. According to the data they obtained, state anxiety levels of the women were found higher than men. These obtained data have the quality to support our study. 
In the study, any statistical difference was not detected in anxiety levels of the students in terms of age variable ( $>>0,05$; Table 3 ). Canan and Ataoğlu (2010) in a similar study, determined that there is no significant relationship between age and anxiety. On the other hand, Güvendi and Bilgin (2016), could not find any statistical significance in football players' anxiety levels in terms of age variable. These above mentioned studies also have quality to support our study particularly. During coronavirus pandemic, experts expressed disease to affect higher age groups. Participants between the ages of 17 and 25 constitute our sample, so age variable can be said not to affect anxiety levels of the participants considerably.

When examined the monthly income variable, no statistical significance was detected (p>0,05; Table 4). Aydin and Tiryaki (2017), could not find any statistical significance between income level and anxiety level. However, anxiety levels of the participants who had lower income level were higher according to the research results. Akgün et al. (2007), in their study, reached the results of no relationship between anxiety levels in terms of income levels. These studies have common ground with our study. Nevertheless, there are some studies indicating the anxiety levels decrease as long as monthly income increase (Saddicha and Khess, 2010; Deveci et al., 2012).

Our study does not display any statistical significance in terms of home exercise status which is thought to be paramount variable ( $p>0,05$; Table 5). According to the data, however, anxiety levels of the participants who do not exercise at home were found higher. In a study conducted by Collingwood et. al. (2000), it was reported that significant decrease in anxiety and depression levels occur due to participation of exercise programs last for 8-16 weeks. In addition, Brown et al. (1992) indicated short duration exercise has positive effects on mental health. In our study, anxiety levels of the students exercise at home were detected lower than those who do not. In another research carried out by Gouttebarge (2020), with 1602 football player during Coronavirus pandemic; depression was observed in $22 \%$ of the female and $13 \%$ of the male while anxiety symptoms were observed in $18 \%$ of the female and $16 \%$ of the male football players. Researcher, in his statement about these above mentioned results, said that 'I worry about this sharp increase in depression and anxiety levels, which was induced of the unprecedented emergency that people had to confront, may be the same in rest of the society.' Therefore, exercise during coronavirus pandemic is thought to affect individual's mental health in positive way according to the obtained data.

No statistical difference was found when exercise frequency and exercise duration of the students were examined ( $p>0,05$; Table 6-7). But anxiety scores of the participants who exercise 5 times and more in a week were found lower, compared to the others. Canan and Ataoğlu (2010), did not discover any relationship between exercise duration and anxiety. However, they found out that anxiety levels of the people who exercise regularly are in lower levels than those who do not exercise, no matter which sports are performed. (WHO, 2006) has encouraged people to make physical activity every day, at least 30 minutes. Besides recommended lower limit of daily physical activity duration is 30 minutes, exercise more than 30 minutes in a daily basis is also believed to have more positive effect on people's health.

Smoking has been commonly explained as a risk factor during the coronavirus by experts. No statistical significance was found in terms smoking status variable in our study $p>0,05$; Table 8 ). But according to the obtained data, anxiety scores of the non-smoker participants were detected lower than those who smoke. When the literature related to this topic is reviewed, studies showing a relationship between smoking and anxiety may be seen (Bjemgaard et al., 2013)

No statistical difference was detected in multiple comparison in terms of status of following coronavirus news $(p>0,05)$. \%81.9 of the participants, however, seem to follow Coronavirus news. This rate demonstrates how much anxiety the people feel about coronavirus.

In conclusion; anxiety levels of the female participants were found higher, compared to men. In our study, no statistical difference was found in terms of home exercise status. Anxiety scores, nonetheless, of the participants who exercise at home were concluded to be lower comparing to the others. As one of the Coronavirus risk factors, smoking was shown to have no significant effect on participants' anxiety levels. But, it was discovered that the students who smoke have higher anxiety levels than non-smokers.

As recommendations for the periods like this; keeping up well-balanced diet, considering 
sleep quality, enhancing immune system and staying away from stress by increasing the motivation, in addition to all of these; low and

\section{REFERENCES}

Akgün, A,, Gönen, S., and Aydın, M. (2007). The investigation of anxiety levels of primary school science and mathematics teacher students' according to some variables, Elektronik Sosyal Bilimler Dergisi; 6 (20), 283-299.

Ateş, E., Canyılmaz, E., Çakır, N. G., Yurtsever, C., and Yöney, A. (2018). Assessment of depression and anxiety states of cancer patients and their caregivers. Ankara Medical Journal, 18 (1), 61-67.

Aydin, A., and Tiryaki, S. (2017). A study on the determination of the factors affecting the anxiety level of university students. KTU sample. Kastamonu Üniversitesi, Orman Fakültesi Dergisi, (4) 17, 715-722.

Bayraktar, G., Tozoğlu, E., and Acar, K. (2014). The effect of sports and other variances on the anxiety level of teacher candidates, Erzincan Üniversitesi, Eğitim Fakültesi Dergisi; 16 (1), 305-315.

Beck, A. T. (2008). Bilişsel Terapi ve Duygusal Bozukluklar (V. Öztürk ve A. Türkcan, Çev.,2. baskı). İstanbul: Litera Yayıncılık.

Beck, A. T., Ward, C. H., Mendelson, M., Mock, J., and Erbaugh, J. (1961). An Inventory for Measuring Depression, Arch Gen Psychiatry, 4:561-71.

Bjemgaard, J. H., Gunnel, P. D., Elvestad, M. B., Davey, S. G., Skorpen, F., Krohan, H., et al. (2013). The Causal role of smoking in anxiety and depression: a mendelian randomization analysis of the hunt study. Psychological Medicine, 43 (4), 711-719.

Brown, S. W., Welsh, M. C., Labbe, E. E., Vitulli, W. F., and Kulkarni, P. (1992). Aerobic exercise in the psychological treatment of adolescents. Percept Motor Skill, 74, 555560.

Byrne, A., and Byrne, D. G. (1993). The effect of exercise on depression, anxiety and other mood states-a review. J Psychosom Res, (37), 565-574.

Canan, F., and Ataoğlu, A. (2010). The influence of sports on anxiety, depression, and moderate intensity exercise are to provide positive effects on anxiety levels of the people.

perceived problem solving ability. Anadolu Psikiyatri Dergisi, (11), 38-43.

Collingwood, T. R., Sunderlin, J., Reynolds, R., and Kohl, J. R. (2000). physical training as a substance abuse prevention intervention for youth. J Drug Educ, (30), 435-451.

Deveci, S. E., Çalmaz, A., and Açık, Y. (2012). The relationship between anxiety level and health, social and demographical factors in the students of a newly established university in Eastern Anatolia. Dicle Tip Dergisi, 39 (2), 189-196.

Dishman, R. K., Renner, K. J., Youngsted, S. D., Reigle, T. G., Bunnel, B. N., Burke, K. A., et al. (1997). Activity wheel running reduces escape latency and alters brain monoamine levels after footshock. Brain Res Bull, (42), 399-406.

Downward, P., Lera-Lopez, F., and Rasciute, S. (2011). The zero-inflated ordered probit approach to modelling sports participation. Econ Model; (28), 2469-2477.

Gouttebarge V. Suddenly young men and women athletes are having to cope with isolation, a suspension of their working lives and doubts about their future. FIFPRO. 20 April 2020 [cited 05 May 2020] Available from:https://www.fifpro.org/en/health/coron avirus-shutdown-sharp-rise-in-playersreporting-depression-symptoms

Güvendi, B., and Bilgin, U. (2016). Investigate the relationship between imagery and trait anxiety in elite academy soccer league players. Uluslararası Hakemli Psikiyatri ve Psikoloji Araştırmaları Dergisi, (7), 762-82.

He, F., Deng, Y., and Li, W. (2020). Corona virus disease 2019 (COVID-19): What we know? Journal of Medical Virology, 0 (2), 1-7.

Ignatowicz, A., Atherton, H., Bernstein, C. J., Bryce, C., Court, R., Sturt, J., et al. (2019) internet video conferencing for patientclinician consultations in long-term conditions: a review of reviews and applications in line with guidelines and recommendations. Digit Health, (5), 1-7. 
Keskin, A., Ünlüoglu, I., Bilge, U., and Yenilmez, Ç. (2013). The prevalence of psychiatric disorders distribution of subjects gender and its relationship with psychiatric helpseeking. Noro-Psikyatri Arsivi, 50 (4), 344351 .

Kinrys, G., and Wygant, L. E. (2005). Anxiety disorders in women: does gender matter to treatment? Revista Brasileira de Psiquiatria, (27), 43-50.

Lawlor, D. A., and Hopker, S. W. (2001). The effectiveness of exercise as an intervention in the management of depression: systematic review and meta-regression analysis of randomised controlled trials, $\mathrm{Br} \mathrm{Med} \mathrm{J}$; (322), 763-767.

Mead, G. E., Morley, W., Campbell, P., Greig, C. A., McMurdo, M., and Lawlor, D. A. (2009). Exercise for depression. Ment Health Phys Act, (2), 95-96.

Öztürk, O. (2004) Ruh Sağlığı ve Bozuklukları. 10. Basım Ankara: Nobel Yayın Dağıtım.

Priya, S. (2020) Singapore Government Launches COVID-19 Chatbot. Available at: https://www.opengovasia.com/singaporegovernmentlaunches-covid-19-chatbot/. Accessed Marc 24, 2020.

Saddichha, S., and Khess, C. J. (2010). Prevalence of depression, anxiety, and stress among young male adults in india. J Nerv Ment Disorders, 198(12), 901-904.

Salmon, P. (2000). Effects of physical exercise on anxiety, depression, and sensitivity to stres: a unifying theory. Clin Psychol Rev, (21), 3361.

Ulusoy, M., Sahin, N., and Erkmen, H. (1998). Turkish version of the beck anxiety inventory: psychometric properties. $J$ Cognitive Psychoter, (12), 163-72.

World Health Organization. Regional Office for Europe. (2006). Physical activity and health in Europe: evidence for action. World Health Organization. Regional Office for Europe. [cited 20 April 2020] Available from: https://apps.who.int/iris/handle/10665/32805
How to cite this article: Acar, K., Mor, A., Baynaz, K., and Arslanoğlu E. (2020). An Investigation on Anxiety States of Students in Faculty of Sport Sciences During COVID-19. Int J Disabil Sports Health Sci;3(1): 66-73. https://doi.org/10.33438/ijdshs.736875 